\title{
A VEROSSIMILHANÇA DA FAMILIARIDADE DO NÃO FAMILIAR NA FICC̣ÃO ANTIGA E MODERNA
}

JoÃo Adolfo Hansen

Universidade de São Paulo

\section{Resumo}

O texto comenta os conceitos de não familiar ou estranho tratados por Freud em Das Unheimliche (1919), associando-os ao hábito e às rupturas do hábito para especificar a diferença da sua ocorrência na experiência individual, em que é significante de uma angústia, e na ficção, em que é figuração intencional. Distinguindo a figuração do não familiar na ficção antiga e na ficção moderna, propõe que na ficção antiga, como a de Luciano de Samósata, o não familiar é classificado platônica e aristotelicamente como fantástico, e na ficção moderna, como a de Beckett, como efeito da crítica e destruição dos regimes de verdade e verossimilhança que fundam a representação.

\section{Abstract}

The text comments the concepts of the unfamiliar and the uncanny as formulated by Freud in Das Unheimliche (1919), associating them to habit and the rupture of habit in order to specify the differences between their occurrence in individual experience, where the uncanny refers to anguish, and in fiction, where it is an intentional representation. Distinguishing the uncanny in ancient fiction from its appearance in modern literature, the text proposes that in ancient fiction, as that of Lucian of Samosata, the uncanny is classified, in accordance with Plato and Aristotle, as fantastic, while in modern fiction, as in Beckett, it is an effect of the critique and destruction of regimens of truth and verisimilitude that are the essential foundations of representation.

\author{
Palavras-chave \\ Estranho, \\ familiar, \\ hábito, \\ verossimilhança, \\ fantástico.
}

\section{Keywords}

Uncanny,

familiar,

habit, verissimilitude, fantastic. 
ethos anthropoi daimon

(caráter do homem (é) demônio) Heráclito de Éfeso

Agradeço a generosidade do convite das caras colegas Cleusa e Yudith para falar aos estudantes de Letras sobre o tema do Unheimlichkeit, a não familiaridade do Unheimliche, não familiar ou estranho, tratado por Freud em seu texto de 1919, Das Unheimliche. O tema é genérico e indeterminado, admitindo muitas abordagens. Outros ocupariam este lugar com mais vantagens para todos aqui. Não sou psicólogo para fazer a teoria psíquica do não familiar, nem psicanalista para propor as condições de teorizar a coisa que insiste e desliza na estranheza dele. Minha fala sobre ele é necessariamente parcial, como fala particular de um professor de literatura que não pretende ser original, nem totalizar nada. Não há totalidade, e começo como sempre se começa: tomando as coisas pelo meio. Aqui, atravessando discursos e sendo atravessado por eles, vou tentar tratar da figuração do estranho na ficção, referindo algumas coisas que foram ditas com ele e sobre ele.

Lacan diz que o homem introduz o significante no mundo, fazendo-o à imagem da Coisa que é impossível de imaginar. Também diz que toda a arte é certo modo de ordenação de formas em torno desse vazio. Eu pensava em relacionar esses dois enunciados lacanianos quando propus para minha fala esse título pesadão, acumulado, "A verossimilhança da familiaridade do não familiar na ficção antiga e moderna". Quero explicá-lo. É de propósito que ele tem essa fórmula aparentemente antitética, "familiaridade do não familiar". Aparentemente antitética porque, como numa fita de Moebius ou garrafa de Klein, a imagem não familiar é efetivamente a face aparente de algo familiar e oculto. No título aplico essa fórmula "familiaridade do não familiar" a dois recortes temporais genéricos, que dou como evidentes por economia do tempo que tenho para falar, "ficção antiga e moderna”. Sei que de modo algum são evidentes, pois basta pensar na multiplicidade indefinida de temporalidades de várias durações que pululam em qualquer tempo histórico para tornar infundadas essas classificações dedutivas de antigo e moderno - ou clássico e barroco, ou clássico e romântico, que a Universidade positiva. Obviamente, quando proponho as generalidades "antigo" e "moderno" não pretendo falar de Deus e sua época, mas de algumas estruturas retóricas de obras da "ficção antiga" - digamos que essa fórmula classifica a generalidade da ficção que foi feita desde os gregos e os latinos até a segunda metade do século XVIII, pressupondo unidades essenciais como fundamento dos discursos de verdade imitados nas obras Ideia platônica, Motor imóvel aristotélico, Deus cristão, razão cartesiana etc. - e da "ficção moderna", digamos a ficção produzida desde as críticas kantianas e os primeiros românticos alemães e ingleses no final do século XVIII e, principalmente, a ficção e a pintura feitas a partir da destruição da representação e das unidades essenciais que a fundamentavam por Baudelaire, Rimbaud, Mallarmé, Cézanne etc. E por que a relação de "ficção" e "estranho"? Digamos que a experiência individual e não ficcional do estranho do não familiar é sempre o inesperado de uma angústia breve e sem palavras, enquanto na experiência da leitura da ficção o estranho do não familiar aparece como efeito ou artifício construído intencionalmente pelo autor, permitindo ao leitor reconhecer a função do fantasma. Nesse sentido, ainda, a figuração ficcional do não familiar pressupõe os diversos regimes de verdade, que desde os gregos fundamentaram as verossimilhanças aplicadas pelos autores. O que vem a ser a verossimilhança?

Desde Aristóteles um discurso é verossímil quando é semelhante a outro tido por verdadeiro. No título da minha fala, uso o termo "verossimilhança" pressupondo essa relação de semelhança entre discursos 
para referir modos históricos de inventar imagens do estranho do não familiar. Nos dois casos, antigo e moderno, quando as obras de ficção põem em cena o não familiar, a forma ficcional da estranheza dele é inventada como uma dessemelhança, que estranha a semelhança familiar que os públicos contemporâneos esperam que o discurso das obras tenha com algo que sua cultura acredita ser o discurso verdadeiro. $\mathrm{Na}$ ficção antiga, a estranheza da falta de semelhança correspondia ao fantástico como o discurso sobre o que não é e que não pode ocorrer, como um diálogo entre mortos ou uma viagem à lua. Na ficção moderna, a estranheza é efeito da destruição sistemática da representação e, por isso, do próprio discurso da semelhança com unidades prévias de verdade. Antes de tratar disso com detalhes e exemplos, retomo o que Freud diz sobre o estranho com a sua lucidez desencantada.

Vocês se lembram, Freud diz que em alemão o termo Unheimliche costuma significar "estranho", "não familiar", "inquietante", "assombroso", "espantoso", "sinistro" e "angustiante", propondo que, nas muitas variações das significações deve haver um núcleo particular constante que vai tentar especificar e definir. De modo geral, embora o Unheimliche seja figurado na ficção, as considerações estéticas pouco tratam dele, provavelmente porque quase sempre só se preocupam em definir o bem feito do belo da arte; como o não familiar geralmente se associa a aspectos considerados insólitos e negativos, muitas vezes feios, sinistros e angustiantes, ele tem pouca definição ou costuma ser definido pelo que falta no bem feito. Freud lembra que, obviamente, o não familiar é um diferencial que varia de indivíduo para indivíduo. Ele pode assombrar justamente porque é insólito, não costumeiro ou novo; mas nem tudo que é insólito ou novo necessariamente assombra. Para especificar ou particularizar o insólito que assombra, Freud usa o adjetivo scherekhaft - assustador - a que se associa o substantivo Schrekgespenst - espectro ou fantasma. Assim, deve haver um diferencial que especifica o insólito como um fantasma com a qualidade do prefixo un, de unheim, o "não" da negação do familiar.

Entre os muitíssimos exemplos que Freud levanta de usos literários e não literários dos termos Heimlich, familiar, e Unheimliche, não familiar, há uma definição feita por Schelling que quero reter e propor-lhes que a lembrem: "Chama-se unheimliche tudo que, devendo permanecer secreto, oculto, no entanto se manifestou".

Freud dá vários exemplos em que o termo Heim tem essa dupla significação indicada por Schelling. Em alemão, Heim significa morada - não o edifício físico, Haus, "a casa", mas o lugar simbólico da habitação do homem, que é uma ausência situada no Outro, além da imagem de que o homem é feito. Quando ela se revela para o indivíduo de que é imagem, o indivíduo vira um objeto estranhado, pois a imagem lhe revela a sua não autonomia como sujeito. Nesse sentido, com Schelling, Freud lembra uma primeira significação do termo Heim - "familiar", "íntimo", "confortável” -, mas, ao mesmo tempo, também "oculto", "dissimulado", "secreto". Nos exemplos que Freud dá dessas significações, o termo Unheimliche aparece como contrário do primeiro significado usual de Heim, ou seja, como contrário de “familiar" e "confortável”, significando "não familiar" e "desconfortável”. Mas não aparece como contrário do segundo significado de Heim, "oculto", "dissimulado". A ambivalência dos usos fica evidente e o termo Heimlich, "familiar", chega a coincidir com sua antítese, Unheimeliche, "não familiar".

Aqui devemos ter em mente essa coincidência porque Freud escreve o ensaio para demonstrar que o não familiar não é algo efetivamente insólito ou novo, mas algo muito familiar na vida psíquica que apenas se tornou estranho por meio de um processo de recalque. Não diz por que é assim ou por que deve ser assim, mas somente que é assim.

Ele lembra que, em geral, o não familiar ocorre quando há dúvida se um ser animado é realmente vivo ou se um objeto inanimado tem vida. No caso, a boneca, o autômato e os processos mecânicos do 
corpo e do discurso que são observáveis na crise epiléptica e na demência são tidos muitas vezes como schrekehaft, assombrosos, sinistros e angustiantes. Ficcionalmente, Freud propõe, é o caso de Der Sandmann, ou "O homem de areia", conto de Hoffmann, autor de narrativas caracterizadas pelo não familiar estranho que costumam ser classificadas como narrativas de horror. Em "O homem de areia", vocês se lembram, Olímpia atrai o personagem masculino que imagina que ela é mulher, não sabendo que é uma boneca com movimentos. Adiante, levado pelo equívoco, o personagem terá os olhos arrancados. Freud diz que a fantasia da perda dos olhos corresponde metaforicamente à angústia da castração e, supondo que essa relação é provável na interpretação do conto, propõe que derivações análogas a essa são aplicáveis a outros casos do não familiar tidos como sinistros. Lembra que as crianças pequenas não traçam limites precisos entre as coisas vivas e os objetos inanimados quando, por exemplo, fazem uma boneca falar conversando com ela. No caso desses jogos infantis, o não familiar não corresponderia necessariamente a uma angústia infantil, mas ao desejo do seu narcisismo primário.

Lembrando a multiplicidade de efeitos semelhantes de não familiar vividos como sinistro, Freud cita o tema do duplo, ou do "outro eu", no qual se transmite para outro ser idêntico e exterior ao eu as características do eu, participando-se no seu ser outro. No caso, há uma repetição do eu que é efetuada como retorno do mesmo da sua identidade suposta de eu em outro, que é um duplo, como o tratado por Otto Rank em seu livro Der Doppelgänger. Freud fala do duplo como princípio de defesa contra a morte e lembra que, na religião egípcia, o duplo do morto acompanhava seu corpo mumificado. Se verificamos sua sugestão e lemos o Livro dos Mortos egípcio, encontramos muitos textos de encantamento escritos desde o Antigo Império, por volta de 2400 a. C., em que Ka é o duplo de Ba, a alma da múmia. Depois que a múmia é posta no túmulo, um sacerdote executa o rito da abertura da boca do morto com instrumentos sagrados que o animam. Ba, sua alma, então revive, livre para sair do corpo e do túmulo e fazer sua viagem diária na barca do deus-sol, Ra, muitas vezes na forma de falcão do seu filho, Hórus, voltando ao túmulo à noite. Enquanto Ba viaja com o deus, seu duplo, Ka, permanece em seu lugar na tumba. $\mathrm{O}$ tema do duplo também aparece no mito grego de Narciso, que vê outro quando vê a si mesmo espelhado na água, e, modernamente, por exemplo, em O retrato de Dorian Gray, de Wilde, em vários textos de Borges e, na versão de Guimarães Rosa, em um só nome, Diadorim, que é um duplo figurando o daimon macho e o daimon fêmea do Eros unidos no andrógino essencial como a ausência ideal que em Grande Sertão: Veredas funda platonicamente a memória do narrador, Riobaldo.

Freud lembra que o narcisismo infantil se caracteriza pela ilimitada egofilia que visa assegurar a sobrevivência da criança. Mas o narcisismo pode se transformar em signo de morte. O princípio do eu que se duplica atua na pulsão de morte da autoconsciência da autocrítica e, em geral, o duplo figura as possibilidades irrealizadas da vida que a imaginação não quer abandonar, produzindo imagens fantasmagóricas. Nas patologias, a tendência defensiva do eu projeta o duplo fora de si como coisa estranha, sinistra e ameaçadora. Freud lembra que, no caso, o duplo é como um espantalho, assim como são os deuses que se transformam em demônios quando desaparecem as religiões que os adoravam, como o daimon grego transformado no demônio dos cristãos.

Jean Pierre Vernant propôs ser possível entender a tragédia grega como figuração do duplo por meio do daimon. Vernant baseia-se em um fragmento hermético de Heráclito de Éfeso que diz éthos anthropoi daimon ou "caráter do homem é demônio". Vernant lembra a perfeita simetria sintática do fragmento e o propõe como possibilidade de entendimento da ação de personagens da tragédia, lembrando a indistinção que o fragmento produz entre éthos, "caráter", e daimon, "demônio", indistinção que permite lê-lo duplamente: "no homem, o que se chama demônio é o seu caráter"; "no homem, o que se chama 
caráter é um demônio". Ou seja: aquilo que faz que um homem seja e permaneça sendo o mesmo homem é justamente um outro, estranho, que ele não domina - ou seja, o que faz com que ele seja o que é ao mesmo tempo é aquilo que o altera, fazendo-o outro e sempre o antecipando, como Clarice Lispector diz em A Paixão segundo G. H.: "o demoníaco é antes do humano".

Mas continuemos com Freud. Retomando o conto de Hoffmann, ele propõe outros transtornos do $e u$ que retomam fases da evolução do sentimento egoico numa regressão a um tempo anterior em que o eu não se demarcava nitidamente frente ao exterior e aos outros. Lembrando esses tempos arcaicos, Lacan fala da experiência sinistra do pesadelo na qual esses tempos, em que a nossa ilustração supostamente nos teria liberado com suas Luzes, retornam no gozo infernal do íncubo e do súcubo que à noite vêm nos assombrar. Lacan associa a experiência angustiante do pesadelo ao grande Outro, propondo que o pesadelo acontece como um enigma do qual o melhor exemplo é a Esfinge mítica, que antecede o drama de Édipo como figura assustadora fazendo questões sobre a identidade.

Freud lembra outros modos de ocorrência do não familiar que são vividos como sinistro e nefasto, como o retorno involuntário ao mesmo lugar por alguém que se perde. Ou o encontro de um mesmo número ou o mesmo nome várias vezes em várias circunstâncias no mesmo dia. Um amigo me contou que sonhou com a infância; no sonho, via os jabutis que a mãe tinha no jardim quando era pequeno. No mesmo dia, leu num jornal uma matéria sobre a apreensão de jabutis pelo IBAMA. À noite, na TV, viu uma notícia sobre animais silvestres brasileiros e lá estavam eles de novo. No dia seguinte foi a uma galeria de arte ver a exposição das gravuras de um artista amigo; saiu, quis almoçar e entrou num restaurante que se chamava Jaboti. Freud diz que a atividade psíquica está dominada por um automatismo de repetição, como compulsiva que tem o poder de se sobrepor ao princípio de prazer como impulso que confere a certas manifestações da vida psíquica um caráter demoníaco. Quem faz a experiência sente o impulso de repetição interior como sinistro.

Depois desses comentários, Freud diz que vai buscar casos indubitáveis de sinistro. Conta o caso de um paciente dele que foi para uma estação de águas e que, tendo ficado muitíssimo bem, teve o juízo de admitir que a melhora não se devia às propriedades medicinais da água, mas ao fato de seu quarto estar ao lado do quarto de uma enfermeira que tinha sido muito, digamos assim, amável com ele. Quando retornou à estação de águas, quis o mesmo quarto, mas ficou decepcionado vendo que estava ocupado por um velho. Com raiva e desgosto, disse: “Quero que ele morra dum ataque!”. Duas semanas depois, o velho morreu e o paciente de Freud achou o acontecimento muito sinistro. Todos os neuróticos obsessivos contam vivências semelhantes em que tiveram ou têm pressentimentos que quase sempre se realizam.

Outra forma sinistra de superstição lembrada por Freud é o terror do mau olhado. Os gregos diziam que os olhos de Apolo matam à distância e até hoje se acredita que o olho dardeja maldades. Por exemplo, quando o canarinho que eu tinha na gaiola morreu, tive certeza de que foi o olho do vizinho que o matou. Quem possui algo valioso, mas perecível, teme a inveja alheia e projeta a própria em outros. E quando alguém se destaca por algo notável, especialmente algo desagradável, supõe-se que sua inveja alcançou uma força especial que poderá se traduzir em atos que ameaçam. Freud diz que esses exemplos se fundamentam na "onipotência do pensamento", propondo que eles remetem a uma velha concepção de mundo conhecida de todos nós, o animismo, a crença na presença de uma multiplicidade de espíritos humanos e não humanos no mundo como crença caracterizada pela superestimação narcisista dos próprios processos psíquicos, pela onipotência dos pensamentos e pelas técnicas da magia baseada na onipotência que atribui forças mágicas a pessoas estranhas e a objetos, como acontece na nossa macumba, no mana polinésio, no numen latino e no daimon grego. Ou na fórmula alemã - ein unheimliches Haus - e portuguesa - uma casa assombrada. 
Em Totem e tabu, Freud escreve: "Pareceria que conferimos caráter 'sinistro' àquelas impressões que tendem a confirmar a onipotência das ideias e o pensamento animista em geral, enquanto que no nosso juízo racional já nos afastamos deles". Ou seja: se todo afeto, qualquer que seja a sua natureza, é um impulso emocional, ele é convertido em angústia pela repressão, sendo preciso que entre as formas do que é angustiante exista alguma na qual seja possível reconhecer que o angustiante é algo reprimido que retorna. $\mathrm{O}$ estranho sinistro do não familiar corresponderia precisamente a essa forma de angústia do retorno de algo familiar recalcado. Se isso é, digamos assim, , o próprio ou o específico do sinistro, é fácil compreender porque a linguagem corrente passa insensivelmente do Heimlich, familiar, para o Unheimliche, não familiar, pois este não seria nada de novo, mas algo que sempre foi e é familiar para a vida psíquica e que só se torna estranho devido a sua repressão. E aqui retorna a definição de Schelling: "Chama-se unheimliche tudo que, devendo permanecer secreto, oculto, no entanto se manifestou".

Muitas pessoas consideram sinistro no grau máximo tudo que se relaciona com a morte, cadáveres, túmulos, cemitérios, aparições de mortos, espíritos, fantasmas, assombrações etc. Por quê? Quando nascemos, mamãe certamente nos deu à luz, mas também nos deu de presente a morte, que desde nosso nascimento determina o que somos. Essa morte dada a priori determina a outra, que cada um de nós felizmente ainda não morreu e que é absolutamente fatal, intransferível e sem nenhuma imagem. O silogismo “Todo homem é mortal, Sócrates é homem, Sócrates é mortal” é lindamente lógico. Mas não consola, pois todos nós vamos ter a não experiência do nada da conclusão dele para nada. Somos feitos de tempo e para essa angústia as religiões propõem a imortalidade da alma nos ensinando a confeitaria, como diz Fernando Pessoa; os poderes do Estado idem: tucaninhos bonzinhos e obedientes agora, enquanto nossas boas intenções se empilham numa montanha de ossos que chega ao céu, depois ganhamos um chocolate. Enquanto dura o durante, o medo da morte faz os mortos serem nossos inimigos, que querem nos levar com seus fantasmas para seu nada sem imagem etc.

Voltando à ficção literária, lembro de novo, com Freud e com Lacan, que há uma diferença fundamental de registro simbólico do estranho na ficção e na experiência não ficcional dele. Na ficção, o estranho sempre é um signo retoricamente construído e encenado de modo intencional, artificial e controlado, que representa alguma coisa não familiar para alguém, um destinatário; na experiência não ficcional, o estranho é a insistência súbita e inesperada e sem controle intencional do significante fugidio de uma angústia individual, que é signo de alguma coisa. Assim, digamos que na ficção o significante do não familiar é um signo convencional e arbitrário controlado pela intencionalidade do ato de fingimento do autor, que constrói uma imagem estranha de angústia que não é nem verdadeira nem falsa, mas possível ou verossímil. A figuração ficcional do estranho de certo modo o naturaliza como algo familiar ao mundo fictício em que ele acontece. Os danados do Inferno de Dante, os fantasmas das peças de Shakespeare, os personagens de Beckett, as muitas GH de Lispector, o índio sobrinho do povo onça de Guimarães Rosa são representações que não parecem realmente estranhas ou não familiares para o leitor e o espectador que aceitam as convenções ficcionais dos textos desses autores. $\mathrm{O}$ autor também pode compor a ficção do estranho como se ele fosse uma estrutura normal, habitual e natural do mundo fictício que inventa. É o que acontece com o horror soturno que escande todas as páginas de A menina morta sem nunca ser dito. Cornélio Penna ia só representar a realidade da família patriarcal na ordem escravocrata do Império, é o que esperávamos com a nossa estupidez realista, mas ele nos arranca ironicamente dessa expectativa e nos entrega à nossa própria superstição animista ao fazer da menina morta um vampiro patriarcal-escravista invisível e indizível que vai sugando a vida de todos e tudo no romance com a sua presença maldita. Outro autor, Kafka, é totalmente sinistro, pois o mundo terrível que inventa é literal e é narrado tão perto, 
tão encostado do olho do leitor, praticamente dentro dele, que impede a interpretação do que ocorre nele como metáfora ou alegoria de outra coisa.

$\mathrm{Na}$ experiência não ficcional, o significante do não familiar é um traço elidido, eliminado, que constitui um sujeito para um indivíduo significante e sua história de vida. No caso, o estranho corresponde à relação que alguém vive com um objeto perdido que obviamente não é perdido por todos os homens ou não é perdido do mesmo modo por todos. Não se trata apenas de perda do objeto, mas de esquecimento da perda. Esquecer alguma coisa não significa que ela deixa de existir e o estranho também pode ser o de algo que insiste momentaneamente como falta no esquecimento da falta, quero dizer, o estranho como a experiência da presença de uma ausência, presença para a qual falta forma imediata, acontecendo para a experiência individual como falta da falta. Assim, quando passa a angústia que a experiência produz, costumamos dizer que "não era nada", transformando a experiência indeterminada do significante elidido no signo substitutivo de uma historinha qualquer que nos tranquiliza até a próxima vez.

A não familiaridade associada à inquietação, ao sinistro, ao mal e à angústia, tanto no caso da ficção quanto no da não ficção, é um efeito de indeterminação. Na ficção, efeito de indeterminação produzido intencionalmente por diversos procedimentos retóricos; na não ficção, efeito produzido por algo e como algo - uso o pronome indefinido neutro "algo" porque é hiperinclusivo e pode significar tudo, isso ou aquilo, atmosfera ou ar estranho, como se diz, objeto inanimado, animal, vegetal, órgão humano, sonho, pesadelo, som, perfume, imagem, palavra, evento etc., algo significante que subitamente desloca alguém da familiaridade da experiência habitual do hábito. O hábito é o que se habita: o hábito é o Heim, "o familiar", de Schelling e Freud.

Qualquer "algo" pode ser não familiar, Unheim, como o inabitado que perturba o hábito com o inabitual. Na ficção, grandes autores como Hoffmann, Nerval, Maupassant, Flaubert, Cortázar, Borges, Rulfo, Rosa, Lispector, Malcolm Lowry, Beckett fazem do neutro do algo o núcleo de suas artes que desterritorializam politicamente o familiar do hábito do leitor, tornando-o inabitado e inabitual. O que caracteriza a indeterminação do algo é a falta de imagem para o buraco negro da falta de significação em que ele joga quem o sofre. Uso o verbo "sofrer" aristotelicamente, como verbo de páthos: a experiência da indeterminação é um afeto vivido como o acontecimento de um efeito intenso, material ou corporal do incorporal da falta momentânea de reconhecimento da falta com que a norma regula a ficção da imagem do corpo próprio como repressão e negação em cada um de nós. A falta súbita da falta da norma ocorre como interrupção do movimento de se estar aí vivo "normalmente", como dizemos com nossa ingenuidade, ou impossibilidade de quem vive a interrupção de reconhecer o que imagina ser o si de si mesmo quando é atravessado e interrompido por ela, falta, que lhe aparece como a obtusidade da incapacidade de traduzila com o familiar que conhece.

Em Clarice Lispector, por exemplo, sempre encontramos a cena arquetípica em que, fazendo contato com o incondicionado ôntico da vida não humana, o personagem intui o arbitrário das normas que regulam sua vida como ser humano marcado pela falta e sonha com a Coisa ou as possibilidades de ser e viver o incondicionado neutro do Outro, vivendo por instantes a experiência de algo atrozmente insípido que poderia ser a liberdade absoluta de uma vida enfim livre das normas que o estruturam como sujeito fraturado de uma história de vida banal, rotineira etc. A continuidade da experiência desse outro é impossível de ser mantida, pois o personagem é só humano, ou seja, um animal do significante, ou seja, o não animal das descontinuidades simbólicas. O simbólico é convenção cultural da imagem do corpo, impossibilidade de passar para o outro lado sem imagem na qual o fundo indeterminado rosna como o lobo mau que vem nos pegar porque ousamos andar fora do Heim do lar, desobedecendo por instantes à 
sabedoria das ordens da mamãe. Mas eu estava preocupado à toa. Não foi nada. Era bobagem. Já passou. Não era nada - dizemos, quando a experiência do não familiar aparentemente termina. Por que dizemos essas coisas sobre a angústia depois? Porque, como Freud viu lucidamente, o Unheim é o Heim, o não familiar é o familiar.

Ou seja, a falta momentânea da norma na indeterminação do estranho se dá como falta momentânea da repressão da falta constitutiva do sujeito que a norma estrutura como hábito. O não familiar do estranho é o recalcado pelo hábito que vem como assombração da casa habitada pelo hábito. Se não os entedio demais, insisto: o termo alemão do texto de Freud, Heim, "familiar", é adjetivo que qualifica o próprio da família ou o habitual do lugar habitado pela norma, o lar.

O termo etrusco lar, que herdamos dos latinos, em latim significava originalmente $d u x$, chefe, guia ou príncipe, ou seja, o principal, que era o principial, o detentor do princípio da lei e das regras, o pai. $\mathrm{Na}$ religião romana, os Lares eram nomes dos espíritos dos antepassados presentes no lar que guardavam a prosperidade da família. Na poesia de Tibulo, por exemplo, eles são custodes agri, guardiães do campo. A presença deles assegurava o princípio da lei do pai que regia o lar como espaço de habitação, tempo do hábito e repetição do costume. Por oposição a Heim, o Unheim ou o estranho do não familiar aparece como o inabitual do inabitado, aparentemente o fora do lugar do lar, aparentemente o vazio sem a lei da presença do princípio do pai. Esse vazio é o não lugar do bicho-papão lá fora, o monstro, que, segundo Freud, é algo familiar que vive dentro do lar.

$\mathrm{Na}$ ficção antiga, o estranho era a figuração do não ser do monstro metafisicamente definido. Como sabem, uma metafísica inaugurada por Platão. Nos Diálogos, ele afirma, contra poetas e sofistas, que só o filósofo como ele o define tem o discurso (lógos) verdadeiro do ser (ousia) de qualquer coisa, pois domina a técnica dialética que lhe permite atingir a Forma essencial dela como alétheia, não esquecimento, verdade ou presença da Presença da Idea da coisa no discurso. Quando desqualifica o discurso do sofista e do poeta, Platão recorre aos dois termos que em grego significam "imagem": eidolon e eikon. Eidolon, termo que deriva do verbo "ver", eidon, significa o duplo de qualquer coisa que se faz passar pelo que não é, como vemos no termo que deriva dele em português, "ídolo". Muito antes de Platão, no episódio da nekyia, a descida ao Hades da Odisseia, Homero fala da sobrevivência da alma dos mortos como eidolon, termo que significa ao mesmo tempo "imagem" e "fantasma". E também skia, "sombra". No canto 11 da Odisseia, Ulisses desce a esse não lugar e diz: "o pálido terror me dominou”. Por que terror? Porque as imagens das almas que Ulisses vê, eidola, são só a presença da ausência de ser figurada como eidolon, "imagem" ou "o duplo do que não é", e skia, "sombra". Nesse sentido, a alma do morto é uma ausência que tem uma imagem que assombra a presença com o horror do não ser.

Quanto ao termo eikon, deriva do verbo eikô, "parecer", "ser semelhante a", e classifica a imagem proporcionada a um modelo, como hoje, em português, no termo "ícone". No Sofista, Platão define eikon como a imagem que tem semelhança com a forma ideal, a Ideia, por oposição a eidolon ou phantasma, que deformam a semelhança como phantásmata, aparências ou não ser. Com os dois termos, eikon e eidolon, Platão define o icástico do eikon como a boa forma proporcionada como semelhança do eidos ou verdade da coisa, opondo-o ao fantástico da forma sem proporção que é efetuada como deformação fantasmagórica dessa semelhança como eidolon, termo que usa também pejorativamente, significando "eidos apequenado".

Com isso, Platão afirma que o discurso do filósofo é icástico e o do sofista e o do poeta, fantásticos. Também afirma que soma sema. Soma, o corpo, é sema, túmulo, túmulo da alma, mas também signo, sema, imagem ilusória da alma. Ou seja: Platão associa a imagem do corpo (soma) ao signo (sema) e, 
simultaneamente, ao túmulo ou à morte (sema). Virgílio retoma essas noções quando diz na Eneida que é fácil descer ao inferno, e Dante, que é impossível sair dele, na Divina Comédia. Virgílio e Dante propõem que a descida aos subterrâneos da casa habitada é um contato fulminante com o não lugar da ausência onde a alma é vida incorpórea sem imagem. É o corpo de quem desce que se torna uma pequena imagem ilusória da coisa que ele quer ver e não vê - o corpo, como pequena imagem degradada ou eidolon do eidos, ídolo do ser, que assombra.

Aristóteles não adota o juízo platônico sobre as imagens quando propõe que a técnica retórica, que Platão desqualifica, é própria das disputas orais da vida civil da pólis. Comparando retórica, ética e dialética, define retórica como técnica de figuração persuasiva das phantasiai dos noeta, as imagens dos conceitos, segundo a doutrina do juízo que expõe no De anima. Na Técnica retórica, diz que "retórica" é a faculdade de descobrir especulativamente aquilo que, em cada caso, pode ser adequado para persuadir. Afastando-se de Platão, valida o to eikós, o verossímil, que Platão julga negativamente como mero eidolon, "imagenzinha" degradada como simulacro da verdade essencial do eidos. Nos Tópicos, Aristóteles fala dos endoxa, os "opináveis" ou "boas opiniões" que parecem verdadeiras para a maioria dos sábios, dizendo que elas fundamentam a verossimilhança na invenção dos discursos. São verossímeis os discursos que se assemelham à opinião, doxa, figurando os endoxa as boas opiniões, segundo o "parecer" mimético. Tratando dos argumentos e exemplos, Aristóteles expõe sua doutrina do verossímil; a doutrina pressupõe especificações, como as que faz sobre o modo como os conceitos se formam na mente, como lemos no Livro III do De anima e nas definições da virtude e dos vícios na Ética a Nicômaco. Nessas especificações, cada gênero do discurso tem um eikós ou verossimilhança própria, que é construída como adequação a um modelo realizado na mente como silogismo ordenado como prépon pelo juízo num ato de deliberação. O discurso verossímil resultante das operações do juízo não reproduz a empiria, mas é uma relação entre discursos operada como a semelhança que pressupõe a comparação do discurso efetuado com outro já existente, que é considerado endoxon, verdadeiro.

Para Platão e para Aristóteles e o cristianismo que os repete, a imagem sempre pressupõe o Ser como fundamento substancial da verdade que ela imita de modo verossímil. Textos de gregos que viveram nos séculos II e III de nossa era, por exemplo os ecfrásticos de Filóstrato, que descrevem pinturas inexistentes, as novelas de Longoe Heliodoro, o Diálogo dos mortos e a História verdadeira, de Luciano de Samósata, têm por referência o não ser, ou seja, o que não é e não pode ocorrer, como textos programaticamente inverossímeis. Escritos contra a metafísica platônica e aristotélica propõem que também o Ser é só um efeito do discurso como qualquer outro. Desde Nietzsche, foram muito valorizados pelos modernos que dissolvem a representação fundamentada metafisicamente em unidades essenciais. Assim, digamos esquematicamente que desde que Aristóteles definiu o eikós, verossímil, como a presença da imagem semelhante ao verdadeiro do Ser, que é uma falta absoluta de imagem, a verossimilhança foi entendida como a imagem que o olho intelectual do juízo vê e reconhece como semelhante ao verdadeiro. Simultaneamente, nos modos antigos de inventar a ficção, a dessemelhança ou a ausência dessa semelhança verossímil sempre foi efetuada retoricamente como "fantástico" - ou no sentido platônico do termo, como depravação, degradação, deformação e misturas monstruosas de imagens icásticas semelhantes ao verdadeiro; ou no sentido aristotélico, como discurso improvável. Falando desse discurso feito por sofistas, Bárbara Cassin dizia que ele não faz ver o Ser mediante um discurso semelhante ao verdadeiro, mas faz ouvir uma paródia dos discursos verossímeis como ficção da ficção.

Assim, falando de modo muito esquemático, as figurações da ficção e das artes antigas - entendendo por "antigo" os modos de inventar as formas fundamentados substancialmente em unidades essenciais, Idea 
platônica, Motor imóvel aristotélico, Deus cristão, Razão cartesiana - a verossimilhança das formas icásticas figura o que é próprio do Ser, e por isso o que é familiar e habitual, enquanto as formas fantásticas figuram o acontecimento impossível do não ser como ficção falsa, monstro, não familiar, inabitual. Desde os gregos até pelo menos a segunda metade do século XVIII, o não familiar foi identificado ao não ser que, não sendo, também não pode ocorrer, e por isso, quando ocorre, é um monstro. Um exemplo moderno de retomada desse fantástico antigo é o Memórias póstumas de Brás Cubas, que, vocês sabem, é escrito por um morto. Machado imita Sterne, que imitou Cervantes, que imitara Ariosto, que tinha imitado Luciano de Samósata.

Digamos, enfim, que a figuração do não ser é não familiar e por isso é como um monstro que rosna contra as identidades que fundamentam as verdades familiares. Porque, repetindo, na ficção antiga, a familiaridade pressupõe e reproduz regimes de verdade que remetem o destinatário a substâncias essenciais postas como identidades prévias que sempre se repetem nas semelhanças que as reproduzem como verossimilhança, desde Platão, em sua caverna psicótica, que quer nos convencer a subir até as ideias essenciais, desprezando o corpo como eidolon fantástico, e depois com Aristóteles e tudo que ele diz dos endoxa, as opiniões verdadeiras que os poetas imitam em discursos verossímeis. E, com o Cristianismo, que é uma versão masoquista de Platão para o povo e por isso não se cansa de propor o mal ou o demônio como ausência do Bem do grande Outro, Deus.

A grande poesia sempre figura a radical estranheza da experiência de tornar o hábito inabitado. A grande poesia é sempre uma experiência do inabitado do hábito como exílio das normas, experiência que é falada naquele lugar onde florescem as flores árticas de Rimbaud na fronteira do Paraguai com a Finlândia. Já leram Celan? Lembrem comigo que na primeira elegia de Duíno, Rilke diz: Wer, wenn ich schriee, hörte mich denn aus der Engeln Ordnungen? ("Quem, quando eu gritasse, me ouviria entre as legiões dos anjos?") para imediatamente dizer que nenhum anjo vem quando o invocamos e que nem animal nem planta respondem ao apelo obscuro da nossa solidão no coração da beleza do mundo. Segundo Rilke, o habitual inabitado dessa solidão humana no coração da beleza do mundo é a estranheza própria da nossa condição determinada pela morte. Essa estranheza continua sendo figurada nessa primeira elegia quando Rilke fala do vento do espaço pleno do mundo que à noite desgasta o nosso rosto com a sua incessante mensagem feita de silêncio. O que a mensagem do silêncio diz é que para nós, que vamos morrer, não há amparo. Porque o sabemos, ficam estranhas as normas familiares do princípio principial do lar que constitui cada um de nós como sujeito confortavelmente habituado ou habitado pela lei do pai, vivendo sem saber que é estruturado como sujeito da falta que a lei fundamenta.

No caso da ficção moderna, que é o que aqui nos interessa, o não familiar é metáfora de uma ausência que desliza no discurso como a presença da falta de norma impedindo que se determine o que ela significa quando ocorre como falta da falta. Na ficção moderna, essa indeterminação artificial pode assumir muitas significações e o sentido delas tem que ser decidido em cada caso. Não é indeterminação substancial, mas diferencial, simbólica, produzida pelo ato fingido da fala fictícia como algo indeterminado. Um poema de Murilo Mendes figura magnificamente esse processo. É breve e o leio:
Algo
O que raras vezes a forma
Revela.
O que, sem evidência, vive.
$\mathrm{O}$ que a violeta sonha.
O que o cristal contém
$\mathrm{Na}$ sua primeira infância. 
Uma amiga e colega nossa, Marília Librandi Rocha, demonstrou, num ensaio sobre esse poema, que o leitor hermeneuta quer saber $o$ quê o poeta quer dizer e pergunta duas coisas: "O que a expressão 'o que raras vezes a forma revela' nomeia?” e “O que a expressão ‘o que raras vezes a forma revela' significa?”, ou seja, o leitor pergunta sobre a referência e a significação. A resposta do que significa é o título do poema, "algo", pronome indefinido neutro, significação metaforizada no poema pelo demonstrativo "o", "aquilo" (de "o que raras vezes", "o que, sem evidência...", "o que a violeta" etc.), que vai nomeando várias referências e que aparece repetido no pronome interrogativo, “o que nomeia? o que significa?", das perguntas do leitor. A resposta "algo" não responde, pois só responde com o deslocamento do pronome interrogativo, que expressa o desejo de verdade do leitor para a diferença da nova resposta dada à nova pergunta - "O que, sem evidência, vive?" - que repete a interrogação, "o quê?"; também repetindo a designação - o demonstrativo "aquilo" de "o que a violeta sonha" - e, de novo, a significação, o indefinido "algo". Enquanto se desloca nas outras questões - "O que é o que o cristal contém?" -, algo retorna e se repete na resposta, engatada na questão inicial - "O que é o que raras vezes a forma revela?" -“" indefinidamente etc.

O pronome indefinido neutro "algo" do título indica ao leitor que a resposta efetivamente é uma quarta "coisa", que não coincide com as três articulações da proposição - a expressão (a dúvida do sujeito que interroga), a designação (a nomeação de referências), a significação (a tradução do poema por "algo"). Essa quarta coisa é o movimento mesmo da diferença, que constitui cada repetição das questões e cada resposta dada a elas como ato singular e mais outro ato singular e mais outro, que jogam o leitor nas estruturas da linguagem entre "o quê?”, o interrogativo que constitui sua carência de sujeito que pergunta, "aquilo", o demonstrativo neutro, signo indicial da designação de referências, coisas e estados de coisas, e "algo", o indefinido neutro, signo geral da significação de significados do poema etc. A quarta coisa é o sentido, que não se confunde com a expressão, nem com a designação, nem com a significação. O sentido é material, pontual e incorporal, como acontecimento sempre diferido e inapreensível no discurso que, no caso, produz e mantém a estranheza.

Grandes poetas como Murilo Mendes querem fazer que o silêncio do estranho diga o que não expressa, o que não designa, o que não significa, estranhando os hábitos do leitor fora do lugar do lar que está habituado a habitar como natural.

Desde a revolução romântica e com a poesia, a prosa e a arte modernas feitas a partir principalmente de Baudelaire, as formas artísticas se autonomizaram de todo fundamento essencial e a produção do estranho passou a ser programática, durando enquanto durou o moderno. Hoje, quando falamos do estranho nesse nosso mundo neoliberal desolado e caduco que a cada dia fica mais e mais deserto e estranho como objetivação crescente da familiaridade global e total da alienação da mercadoria, as artes e a ficção contemporâneas abandonam o projeto moderno de efetuar programaticamente o estranho e, cada vez mais e mais narcísicas e regressivas, integram-se às novas formas do capital como divertimento e distração. Hoje, a maior estranheza é a da normalidade da nossa vida dita pós-moderna que frequenta os nossos pesadelos. Nos modos antigos de representar, a semelhança produzia diferenças que eram domadas negativamente como não ser por unidades essenciais dadas como primeiras; nos modos modernos, que negam o platonismo ou a metafísica, a diferença produzia semelhanças arbitrárias, sem primeiro ou unidade essencial. Ou seja, nos modos modernos de inventar a ficção, a dessemelhança era efetuada retoricamente como diferença sem semelhança com nada.

Em ambos os casos, antigo e moderno, o estranho se efetuava como figuração que produzia o vazio do texto de que falou Iser e que os formalistas russos chamaram de ostranenie, estranhamento, definido como elemento fundamental do procedimento técnico posto a nu como crítica da representação que 
caracterizou a grande arte moderna. Evidentemente, a relação de determinado/indeterminado é cultural, ou seja, convencional e arbitrária, e sempre pressupõe os sistemas de representação com que uma formação histórica particular ordena as normas que estruturam, regulam, controlam e naturalizam os hábitos como familiaridade.

O que é o hábito? Repetição. Na repetição, as novas experiências são traduzidas como diferenças semelhantes às repetições anteriores que já foram vividas; na experiência do não familiar, a diferença sem semelhança da indeterminação domina momentaneamente o sujeito com uma angústia que é curtocircuito de suas representações habituais do espaço-tempo do lar. Por outras palavras, na experiência da indeterminação da angústia do não familiar, estão presentes os modelos culturais que regulam as coisas como a normalidade do que é determinado. O que é determinado como habitual é previsível e, por isso, também é imaginado e vivido como natural. A não familiaridade da indeterminação que perturba o reconhecimento do habitual é tida como imprevisível, anormal ou não natural.

Temos aqui três pares de oposições complementares associadas ao par familiar/não familiar: natural/não natural, normal/anormal, habitual/inabitual. Pensemos, por exemplo, num grande escritor moderno, Beckett e, por exemplo, no seu livro terrível, O inominável. Geralmente se acredita que o corpo é uma unidade decorrente da integração de partes, membros e órgãos a uma finalidade, como a de ser veículo da alma cristã ou a de ser suporte e veículo da identidade do sujeito que o habita recitando uma historinha de vida liberal, individual e social. O corpo que a voz narrativa de $O$ inominável figura como sendo o seu não tem essa unidade suposta. Faltam-lhe órgãos. Dessubjetivado, é corpo cômico. E não porque faça rir. O humor negro da invenção dele é feroz, mas ele não faz rir. É cômico porque deformado, mas sem que a deformação dele possa ser entendida platônica ou aristotelicamente ou cartesianamente ou kantianamente ou hegelianamente como derivação, desvio ou distorção de qualquer unidade prévia de significação e sentido.

Como disse, na figuração antiga e na representação realista que Beckett destrói, a deformação do estranho sempre era uma diferença definida e capturada como semelhança degradada de um modelo unitário - com iniciais maiúsculas, o Ideal, o Essencial, o Um, o Uno, o Deus, o Belo, o Bom, o Justo, o Natural, o Racional, o Científico, o Ideias-No-Lugar, o Nacional, o Formado, o Formatado etc. Como outros grandes artistas modernos - pensemos em Picasso, Giacometti, Dubuffet, Bacon -, Beckett produz deformação imanente, deformação sem primeiro ou sem modelo: em $O$ inominável, o corpo que a voz inventa se repete deformado em si mesmo sem nariz, sem orelhas, sem pálpebras, sem sexo, encharcado de lágrimas involuntárias que choram sem parar por nada e por ninguém. Às vezes, ele também é corpo da tartaruga sem pescoço que pensa sobre conserva de carne de cavalo com o queixo apoiado na borda do vidro de conserva onde a dona a colocou, tartaruga que imagina a altura de sua cabeça oval ou pontuda de cumeeira de casa onde longos pelos duros nascem espetados como os pelos duros e longos que nascem espetados nas pintas dos corpos dos velhos. Ironicamente, é mais exato dizer que é um corpo-ovo médio, ou seja, um corpo-cilindro pequeno, ou seja, um corpo que realmente é um corpo-bola, algo grande. Como um chiclete nos dentes, é corpo quodlibet, que assume forma conforme a pressão da força que outra coisa que se conecta com ele como órgão, prótese física ou prótese espiritual exerce sobre ele quando o penetra, alisa, enruga, esfria, chupa, encolhe, enrola, esquenta, mastiga, corta, tortura, engole, defeca etc. A multiplicidade das suas conexões com outros órgãos faz o eu da voz de $O$ inominável ser como o eu de um pólipo e elimina a exclusividade de um só eu subjetivado para ele, pois permite que as legiões infindáveis dos outros eus de outros órgãos coexistam coletivamente nele, o que não impede que ele saiba, por exemplo, que se suas 
órbitas escorrem lágrimas, sempre é possível tapá-las com outros órgãos e também secá-las com outros e mais outros. Com as conexões, é possível acabar com o choro, que não escorre mais, e acabar com uma de suas causas que, ao desaparecer, ou dói ou não dói mais. Em cada um desses processos, vários eus e quase-eus larvares são produzidos sem que nenhum deles seja o primeiro ou principal ou principial. Do mesmo modo (ainda falando de pálpebras), pode-se aplicar o efeito contrário com outro órgão para efetuar outro "eu" parcial: quando se destapa a pálpebra aplicada como tapa-olho no lugar da pálpebra original que caiu, pode-se produzir algum pranto eficaz, que molha a barriga enfiada no chão preto. E quando se admite que a forma do corpo é a de uma bola, isso também permite variar sua posição de equilíbrio apoiando-se alternadamente sobre um de seus muitos polos. Cada apoio permite variações físico-psico-lógico-político-sentimental-estético-espirituais muito variadas. E permite dizer que é corpo redondo, sem aberturas e asperezas, ou que é grande como a estrela Sirius no Cão Maior, ou que é totalmente invisível, permitindo compor outros eus como sujeitos de enunciação e sujeitinhos dos enunciados de outros trechos de discursos diversos.

Se lembramos o modelo clássico-romântico-realista-naturalista-organicista da representação do corpo esse que é o nosso, de partes e órgãos gregários como carneirinhos disciplinadamente subordinados à Grande Saúde norte-americana assegurada pela Ordem do Pai fixada paranoicamente no céu do nosso cu como um parafuso-motorzinho-órgão de dúvida e culpa metódicas - pode-se perguntar com candura: mas como é possível para a voz de O inominável escrever se o braço e a mão do seu não corpo estão presos no chão, não se sabe bem como nem por quem nem por que nem para quê? Como a voz pode ser tão declaradamente e tão descaradamente cínica com o leitor desse jeito tão estranho e tão improvável e mesmo tão impossível de ser?

Beckett nos propõe que é preciso barrar a linguagem, opor-lhe resistência com o não corpo como um dique, uma barreira impedindo que ela encharque todos os espaços com um sentido. Quando a linguagem domina, Beckett propõe, deliramos falados por ela. A voz de $O$ inominável é ferozmente lúcida, não quer ser falada pelas significações existentes, que falseiam a experiência crua da sua liberdade que sabe que vai morrer acumulando o cansaço de todas as experiências das vozes que convergem nela sem querer dar um sentido para elas. O que faz é evidenciar que sempre há uma multiplicidade monstruosa de orientações simultâneas relacionando arbitrariamente seu não corpo com as coisas do mundo. Não há um sentido nessas orientações, que são vetores estabelecendo relações. Um deles, por exemplo, é crer na morte. Isso não dá nenhum sentido à experiência, pois a morte é nada e todos continuam morrendo. Mas é uma orientação que permite à voz continuar eliminando um sentido, sem crer, ou seja, livre, pois crer é obedecer. Assim, a voz não tem nenhum interesse pelos conteúdos da sua fala. Ela não fixa nenhum significado deles como Primeiro, Essencial, Transcendente, Totalizante, Fundante, Originário, Formador etc. Indiferente aos significados, a voz está cansada de histórias. Indiferente ao sentido, está esgotada pela História e quer a enunciação que aponta o silêncio. Silêncio que aparece não familiar e estranho para o leitor.

Disse antes que a ficção antiga era regrada por critérios retóricos normativos quando produzia o icástico, ou o discurso semelhante ao verdadeiro do ser, e o fantástico, o discurso impossível do não ser sem semelhança com o ser. No caso da literatura e das artes modernas, principalmente as do século XX, o não familiar também é regrado retoricamente, mas os critérios não são normativos, mas singulares, sendo efetuados como o que podíamos chamar, com Deleuze, de figural e visionário, como em Beckett, que leva a estranheza às últimas consequências da singularidade demonstrando que a linguagem sempre mente.

Em todos os casos, o que está em jogo na especificação do não familiar na ficção são os regimes de verdade e as verossimilhanças e destruições das verossimilhanças implicadas neles. Mas não há mais tempo e paro por aqui, nesta metade. Obrigado pela sua atenção. 